\title{
EKSISTENSI PERNIKAHAN PEREMPUAN SAYYID DI DESA CIKOANG KABUPATEN TAKALAR
}

\author{
Edi Hariyadi ${ }^{*}$, Firdaus W Suhaeb ${ }^{2}$ \\ ${ }^{1}$ Mahasiswa/Sosiologi \\ Universitas Negeri Makassar \\ Email: edihariyadi14@gmail.com \\ ${ }^{2}$ Dosen/Sosiologi \\ Universitas Negeri Makassar \\ Email:
}

\begin{abstract}
ABSTRAK
Pernikahan kalangan sayyid yang terjadi di masyarakat Desa Cikoang Kabupaten Takalar merupakan salah satu ciri pembeda bagi masyarakat biasa dalam melaksanakan pernikhannya, yaitu terdapat aturan tersendiri bagi perempuan kalangan sayyid, yakni perempuan sayyid tidak bisa menikah dengan laki-laki yang bukan dari keturunan kalangan sayyid atau keturunan dari Nabi Muhammad SAW. Pendekatan penelitian menggunakan metode kualitatif deskriftif yang dilaksanakan di Desa Cikoang Kabupaten Takalar. Data primer diperoleh dengan cara observasi, wawancara, dokumentasi. Data sekunder bersumber dari buku dan jurnal. Penelitian ini menunjukkan bahwa cara melestarikan pernikahan tetap eksis sampai sekarang yakni, faktor kepercayaan, mereka percaya bahwa para keturunannya barasal dari keturunan Nabi Muhammad SAW. Dan faktor aturan, dimana kalangan sayyid memiliki aturan dalam melaksanakan pernikahan yakni perempuan sayyid tidak bisa menikah dengan laki-laki yang bukan dari keturunan sayyid, akan tetapi laki-laki sayyid bisa menikahi perempuan diluar kalangannya. dan faktor saksi, yaitu bagi perempuan yang melanggar aturan tersebut akan dikenakan sanksi berupa tidak lagi dianggap dlam keluarganya dan kalangannya sebagai keturunan sayyid dan sudah dianggap meninggal. Sedangkan pemberian solusi bagi perempuan sayyid yang tidak memiliki pasangan di kalangannya adalah menjodohkan dengan lakilaki sayyid. Dan solusi keduanya ialah memperbolehkan perempuan sayyid menikah dengan sanksi yang berlaku.
\end{abstract}

Kata kunci: kepercayaan, aturan, dan sanksi

\section{ABSTRACT}

Sayyid marriages that occur in the community of Cikoang Village, Takalar Regency are one of the distinguishing characteristics for ordinary people in carrying out their marriages, namely there are separate rules for sayyid women, namely Sayyid women cannot marry men who are not of Sayyid descent or descent of the Prophet Muhammad SAW. The research approach used descriptive qualitative methods carried out in Cikoang Village, Takalar District. Primary data obtained by means of observation, interviews, documentation. Secondary data comes from books and journals. This research shows that the way to preserve marriage still exists today, namely, the factor of 
belief, they believe that their descendants come from the descendants of the Prophet Muhammad. And the rule factor is that sayyid circles have rules in carrying out marriage, namely sayyid women cannot marry men who are not of Sayyid descent, but sayyid men can marry women outside their circle. and the witness factor, namely for women who violate these rules will be subject to sanctions in the form of no longer being considered in their family and among their circle as Sayyid descendants and are considered dead. Meanwhile, the solution for Sayyid women who do not have a partner among them is to match a Sayyid male. And the second solution is to allow Sayyid women to marry under the applicable sanctions.

Keywords: Trust, Rules, and Sanctions

\section{PENDAHULUAN}

Keturunan sayyid adalah golongan keturunan Al-Husain, cucu Nabi Muhammad SAW. Mereka bergelar habib bagi anak laki-laki dan anak perempuan bergelar habah. Kata sayyid yang hanya digunakan sebagai atribut atau keterangan. (Indah Rezky Muliah dalam Azis, 2018). Keluarga ialah lembaga sosial dasar dari mana semua lembaga atau pranata sosial lainnya berkembang. Di masyarakat manapun di dunia, keluarga merupakan kebutuhan manusia yang universal dan menjadi pusat terpenting dari kegiatan dalam kehidupan individu (Narwoko, 2004). Syarat untuk membentuk suatu keluaraga di Indonesia lebih khususnya di Bugis Makassar haruslah dimulai dengan prosesi perkawinan atau pernikahan. Dalam melakukan prosesi pernikahan di Bugis Makassar yang syarat akan budaya, tradisi, dan nilai dan norma yang di anut serta kepercayaankepercayaan yang diwariskan para lelehur mereka menambah rumitnya dalam melaksanakan prosesi pernikahan yang harus dijalani dan hal ini tidak boleh dilanggar. Kalangan sayyid menganut sistem perkawinan yakni Endogami, Endogami adalah perkawinan yang dilakukan dengan seseorang yang berasal dari lingkungan sendiri. Lingkungan itu bisa jadi dalam satu desa, satu clan, satu marga atau satu keluarga dekat, tetapi sudah bukan muhrimnya. (Torro, 2013). Pernikahan kalangan sayyid merupakan ciri pembeda bagi masyarakat biasa atau bukan kalangan sayyid. Di mana kalangan sayyid jika anak perempuannya (sarifah) hendak dinikahi oleh masyarakat atau kalangan non-sayyid sangat tidak diperbolehkan meskipun laki-laki yang hendak menikahinya tersebut merupakan sosok yang terpandang ataupun memiliki strata sosial yang tinggi tetap tidak diperbolehkan. Namun anak laki-laki pada keturunan kalangan sayyid bisa secara bebas menikahi gadis atau perempuan yang bukan kalangan sayyid, sekalipun perempuan yang ingin dinikahinya memiliki strata sosial yang rendah, tidak memiliki keturunan bangsawan. Jika aturan atau proses itu dilanggar oleh perempuan (sarifah) keturunan kalangan sayyid maka akan mendapatkan konsekuensi, yakni di keluarkannya 
anak perempuan tersebut dalam keturunan kalangan sayyid dan anggota keluarganya, serta sudah dianggap meninggal atau tidak pernah terlahir didunia. Penelitian ini ingin memahami 2 rumusan masalah: 1) Bagaimana cara melestarikan pernikahan di kalangan keturunan sayyid sehingga tetap eksis sampai sekarang, 2) Bagaimana solusi yang diberikan terhadap perempuan (sarifah) yang tidak memiliki pasangan di kalangannya.

\section{METODE}

Jenis penelitian yang digunakan dalam penelitian ini adalah penelitian kualitatif dengan pendekatan deskriptif. Pendekatan deskriptif dalam penelitian ini bertujuan untuk menggambarkan secara sistematis dan akurat mengenai fakta-fakta dan sifat-sifat populasi di daerah tertentu. Penelitian ini dilakukan untuk mendapatkan gambaran kusus mengenai "eksistensi pernikahan perempuan sayyid di Desa Cikoang Kabupaten Takalar" . lokasi penelitian berada di Desa Cikoang Kabupaten Takalar. Tehnik pengumpulan data yang digunakan adalah observasi, wawancara, dan dokumentasi. Dengan menggunakan teknik purposive sampling ialah teknik memilih sampel dan data dengan pertimbangan tertentu sesuai kriteria penelitian (Sugiyono.2013).

\section{HASIL DAN PEMBAHASAN}

Penelitian teori ini menggunakan teori Struktural Fungsional. Teori Struktural Fungsional menekankan pada keteraturan (order) dan mengabaikan konflik dan perubahan-perubahan dalam masyarakat. Konsep-konsep utamanya adalah: fungsi, disfungsi, fungsi laten, fungsi manifest, dan keseimbangan (equilibrium).Menurut teori ini masyarakat merupakan suatu sistem sosial yang terdiri atas bagian-bagian atau elemen yang saling berkaitan dan saling menyatu dalam keseimbangan. Perubahan yang terjadi dalam suatu bagian akan membawa perubahan pula terhadap bagian yang lain. Asumsi dasarnya adalah bahwa setiap struktur dalam sistem sosial, fungsional terhadap yang lain. Sebaliknya jika tidak fungsional maka struktur itu tidak akan ada atau akan hilang dengan sendirinya (Ritzer, 2016).

Pembahasan menyangkut Struktural fungsional Parsons ini akan dimulai dengan empat skema AGIL. Dengan memakai defenisi ini, parsons meyakini bahwa terdapat 4 perang urgent yang diperlukan semua sistem, diantaranya: Adaptation (A) goal attaiment (G) integration (I) latency (L). Secara bersamaan, ke-empat imperatif fungsi ini dekenal dengan sebagai skema A.G.I.L. Agar tetap eksis, suatu sistem harus memiliki empat fungsi ini sebagai berikut: 
1. Adaptation (adaptasi): sebuah sistem harus menanggulangi situasi eksternal yang gawat. Sistem harus menyesuaikan diri dengan lingkungan dan menyesuaikan lingkungan itu dengan kebutuhannya.

2. Goal attainment ( pencapaian tuijuan): sebuah sistem harus mendefenisikan dan mencapai tujuan utamanya.

3. Integration (integrasi): suatu sistem harus mengatur antar hubungan bagianbagian yang menjdi komponennya. Sistem juga harus mengola antarhubungan ketiga fungsi penting lainnya ( $A, G, L)$.

4. Latency (pemeliharaan pola): sebuah sistem harus melengkapi, memelihara dan memperbaiki, baik motivasi individual maupun pola-pola kultural yang menciptakan dan menopang motivasi. (Parsons dalam Ritzer, 2014).

\section{Bagaimana cara melestarikan pernikahan di kalangan keturunan sayyid sehingga tetap eksis sampai sekarang}

Beberapa faktor yang membuat pernikahan ini tetap lestari yakni:

\section{a. Kepercayaan}

Kepercayaan merupakan modal utama yang sangat penting bagi suatu kebudayaan agar tetap bertahan. Dikomunitas keturunan sayyid ideologi tersebut masih terbangun dengan sangat baik sampai saat ini. Berikut kutipan wawancara:

"Sebagian besar berpendapat mengatakan bahwa Nabi Muahammad SAW adalah manusia biasa, akan tetapi menurut keyakinan dan para Sayyid beserta pengikutnya tidak demikian, Nabi Muhammad SAW memang dicipta kusus. Nabi Muhammad SAW dicipta oleh Allah SWT dengan Nur (cahaya) menurut pendapat kita semua para kalangan sayyid kususnya di Cikoang.

Bukan berarti kami menggap enteng sesama manusia, akan tetapi begitulah perintah Allah SWT sesuai pengetahuan kami disini. Yang mengatakan bahwa setiap anak cucu turunan dari Nabi Muhammad SAW tidak diperkenankan menikah diluar kalangan. Itulah sebanya kita masih memegang teguh aturan ini.Sabda Nabi Muhammad SAW mengatakan bahwa semua anak yang dilahirkan oleh ibunya bernasab kepada ayah mereka kecuali anak-anak fatimah, akulah wali mereka, akulah nasab mereka, dan akulah ayah mereka. sambung beliau. (Sayyid Makkatan Siriwa Tuan Siriwa, hasil wawancara 28 juni 2020)". 
Informan mengutarakan bahwa kepercayaan mereka tidak memperkenankan sarifah atau anak perempuannya menikah dengan laki-laki yang bukan dari kalangan sayyid, dan itu merupakan perintah dari Nabi Muhammad SAW menurut kepercayaan mereka.

\section{b. Aturan}

Aturan merupakan suatu bagian penting yang terdapat dalam sebuah kelompok atau komunitas untuk menjaga batasan-batasan dalam berlaku hidupan sehari-hari. Aturan disini sangat penting dalam mengatur kehidupan suatu komunitas atau kelompok terutamanya Para keturunan kalangan Sayyid di Cikoang Kabupaten Takalar. Berikut kutipan wawancara:

"kalau dilihat dari sudut pandang kita itu,yang suku Makassar dan suku Bugis tidak ada masalah ketika menikah, yang jadi masalah itu ketika keturunan habaib atau keturunan sayyid yang menikah di luar kalangan, yang keturunan sayyid (sarifah) itu yang tidak bisa menikah dengan orang luar kalau bukan keturunan habaib atau sayyid. Makanya seluruh dunia aturan ini berlaku bukan hanya dicikoang saja. Kalau dia senasab dari keturunan sayyid juga tidak ada masalah biarpun di jawa dengan disini boleh asalkan sama-sama sayyid. itu saja hukumnya atau aturannya. (Habib Anwar S.Pdi. Tuan Lenbang, Hasil wawancara (24 juni 2020)”.

Dari apa yang dipaparkan informan bahwa bagi pasangan yang bukan dari kalangan sayyid bisa secara bebas menikah dengan pasangannya selama dia saling suka, akan tetapi aturan itu tidak berlaku pada kalangan sayyid yang memiliki aturan yang tidak memperkenankan sarifah mereka menikah dengan laki-laki yang bukan dari keturunan sayyid.

\section{c. Sanksi}

Proses pernikahan pada umumnya tidak ada sistem pemberlakuan sanksi pada sicalon pengantin maupun keluarganya selama mereka saling suka sama suka dan mendapat restu dari kedua orang tua mereka, akan tetapi perihal itu tidak berlaku padaprosesi pernikahan keturunan kalangan sayyid yang memiliki kepercayaan, aturan, serta sanksi yang berlaku dalam pernikahan mereka hingga saat ini. Berikut kutipan wawancara: 
"Jikalau seorang sarifah sudah kawin dengan lelaki yang tidak bernasab dari golongan sayyid maka dia sendiri yang mengeluarkan dirinya dari nasab, dan apabila dia sudah keluar dari nasab maka sudah dianggap tidak ada atau sudah dianggap meninggal. Bukan hanya di dunia mendapatkan sansi sesama kalangannya, akan tetapi di hari akhirat nanti akan mendapatkan sansi dari Allah SWT. Dan bukan hanya sarifah yang mendapatkan sansi di akhirat nanti, akan tetapi laki-laki yang bukan dari kalangan sayyid dan menikahi kaum sarifah juga akan mendapatkan sansi di akhirat kelak. (Sayyid Tuan Jamahari, hasil wawancara 25 juni 2020)”.

Apa yang dikemukakan oleh narasumber bahwasanya bagi sarifah yang melanggar aturan akan mendapatkan sanksi berupa dikeluarkan dikalangan sayyid dan sudah dianggap meninggal, dan bukan itu saja akan tetapi di akhirat nanti juga akan mendapatkan sanksi, menurut apa yang mereka percayai.

\section{Bagaimana solusi yang diberikan terhadap perempuan (sarifah)yang tidak memiliki pasangan di kalangannya}

\section{a. Dijodohkan sesama kalangan sayyid}

Dikarenakan perempuan sayyid memliki batasan dalam memilih laki-laki untuk mempersunting mereka, maka dari itu orang tua kalangan sayyid berusaha mencarikan jodoh atau laki-laki sayyid untuk mempersunting anak perempuannya. Berikut kutipan wawancaranya:

"Sudah menjadi aturan dalam keluarga kalangan Sayyid untuk menikah sesama kalangan, maka orang tua memberikan solusi dengan cara memperjodohkan anak perempuannya (Sarifah) dengan laki-laki yang berketurunan Sayyid seperti sepupu ataupun keluarga jauh lainnya. Akan tetapi jika suatu sarifah tidak ada yang melamar dari kaum Sayyid maka lebih baik menjadi perawan tua daripada berumah tangga dengan yang bukan berasal kalangan Nabi Muhammad. (Sayyid Makkatang Siriwa Tuan Siriwa, hasil wawancara 28 juni 2020)”. 
Jurnal Predestination: jurnal of Society and Culture.

Dari apa yang disampaikan oleh narasumber, mencarikan jodoh bagi anak perempuannya sudah menjadi kewajiban bagi orang tua untuk mencarikan jodoh bagi anak perempuannya agar tidak keluar dari keturunan kalangan sayyid.

\section{b. Menikah diluar golongan dengan sanksi yang berlaku}

Tidak berbeda dengan aturan yang berlaku dalam kalangan sayyid yang sebelumnya, meskipun dalam keluarga keturunan kalangan Sayyid tersebut hanya memiliki satu anak perempuan atau sarifah ataupun anak tunggal. dan jika aturan yang dianut dalam kalangan sayyid tersebut dilanggar makan akan mendapatkan sanksi yang sama yang berlaku sejak dahulu. Berikut wawancaranya:

"Semisal ada orang tua mengijinkan anak Sarifahnya menikah dengan bukan kalangan sayyid maka orang tuanya juga akan dikeluarkan dari kalangan sayyid" (Sayyid Muh Arif Tuan Lolo, hasil wawancara 25 juni 2020)”.

Berdasar pada wawancara di atas, dapat dilihat bahwa aturan serta sanksi ini sangat keras bahkan jikalau suatu orang tua merestui anak perempuannya menikah dengan laki-laki yang bukan dari kalangan sayyid maka orang tua nya juga akan dikeluarkan di kalangan sayyid itu sendiri.

\section{KESIMPULAN}

Dari hasil penelitian ini menunjukkan bahwa ada beberapa indikator yang membuat pernikahan ini tetap eksis sampai sekarang, yakni: a) kepercayaan, dimana kalangan sayyid mempercayai bahwa garis keturunan mereka berbeda dengan keturunan Nabi Adam AS yang terbuat dari tanah, sedangkan keturunan mereka berasal dari Nabi Muhammad SAW yang tercipta khusus dari Cahaya. Dan itulah yang melatar belakangi sehingga pernikahan sayyid dan non sayyid tidak diperkenankan. b) aturan, aturan yang berlaku dalam kalangan sayyid hanya terdapat satu aturan yakni, sarifah atau perempuan kalangan sayyid todak diperbolehkan menikah dengan laki-laki yang bukan dari kalangan sayyid. c) sanksi, dimana jikalau seorang sarifah melanggar aturan tersebut maka akan mendapatkan sanksi berupa dikeluarkan dari kalangan sayyid dan keluarganya serta sudah dianggap meninggal ataupun tidak pernah terkahir didunia. 
Dan pemberian solusi bagi perempuan atau sarifah yang tidak memiliki pasangan dikalangannya, yakni: a) dijodohkan, para orang tua sarifah berusaha mencarikan jodoh dengan sesama kalangannya bahkan diluar daerah sekalipun asalkan laki-laki tersebut berasal dari keturunan sayyid. b) menikah diluar kalangan dengan sanksi yang berlaku, hal ini ditujukan kepada kaum sarifah yang tidak kuat kepercayaannya, akan tetapi jikalau si sarifah tersebut kuat dengan keyakinannya maka tidak akan menikah dengan laki-laki yang bukan dari kalangan sayyid.

\section{DAFTAR PUSTAKA}

Azis s, Nurbaya. 2018. Budaya Siri' Pada Masyarakat Sayyid di Cikoang. Skripsi. Fakultas Adab dan Humaniora. Universitas Islam Negeri Alauddin Makassar: Makassar.

Narwoko Dwi, suyanto Bagong. 2004. Sosiologi Teks Pengantar dan Terapan. Jakarta: Prenadamedia Group.

Ritzer George. 2014. Teori Sosiologi Modern. Jakarta. Kencana.

Ritzer George. 2016. Sosiologi Ilmu Pengetahuan Berparadigma Ganda. Jakarta. Rajawali Pers.

Sugiyono. 2013. Metode penelitian pendidikan pendekatan kuantitatif, kualitatif $R \& D$. Bandung. Alfabeta.

Torro, Supriadi dkk. 2013. Kelompok Strategis dalam Masyarakat. Makassar. Badan Penerbit UNM. 